\title{
Roles of Apolipoproteins B and E in the Cellular Binding of Very Low Density Lipoproteins
}

\author{
E. S. Krul, M. J. Tikkanen, T. G. Cole, J. M. Davie, and G. Schonfeld \\ Lipid Research Center, Departments of Preventive Medicine, Medicine, and Microbiology and Immunology, \\ Washington University School of Medicine, St. Louis, Missouri 63110
}

\begin{abstract}
Apoproteins B and E both interact with cellular low density lipoprotein (LDL) apolipoprotein B and E (apo B,E)-receptors, and very low density lipoproteins (VLDL) contain both apo B and apo $E$. Our aim was to study the relative importance of apo $B$ and apo $E$ in the binding of VLDL subfractions to cells. Two monoclonal anti-LDL-apo $B$ antibodies (464B1B3 and $464 \mathrm{B1} B 6,2 \mathrm{a}$ and $2 \mathrm{~b}$, respectively) and two anti-apo $\mathrm{E}$ antibodies (1506 A1.4 and 1907 F6.4) were used to inhibit lipoproteincell interactions.

In confirmation of previous findings, the binding and degradation of ${ }^{125} \mathrm{I}-\mathrm{LDL}$ by human fibroblasts were inhibited $\sim 90 \%$ by antibodies $2 a$ or $\mathbf{2 b}$ or the antigen-binding fragments of $2 \mathrm{a}$, whereas the cellular processing of ${ }^{125} \mathrm{I}_{-} \mathrm{VLDL}_{3}\left(\mathrm{~S}_{\mathbf{r}} 20\right.$ 60), ${ }^{125} \mathrm{I}_{-V L D L}\left(\mathrm{~S}_{6} 60-120\right)$, and ${ }^{125} \mathrm{I}_{-} \mathrm{VLDL}_{1}\left(\mathrm{~S}_{\mathrm{f}}>120\right)$ were inhibited by only $\sim \mathbf{5 0} \%, \sim \mathbf{2 5 \%}$, and $<\mathbf{1 0} \%$, respectively. The VLDL $_{1-3}$ and LDL-dependent intracellular esterification of cholesterol with $\left[{ }^{3} \mathbf{H}\right]$ oleate were inhibited to a similar extent. Other monoclonal anti-human apo $B$ antibodies inhibited lipoprotein-cell interactions much less effectively and nonimmune IgG isolated from mouse serum did not inhibit at all. 20-fold excesses of LDL produced about the same patterns of inhibition of degradation of ${ }^{125} \mathrm{I}_{-} \mathrm{VLDL}_{1-3}$ and $\mathrm{LDL}$ by cells as did antibodies $2 a$ and $2 b$, whereas homologous unlabeled $V_{L D L}$ in like amounts inhibited the matched ${ }^{125}$ I-VLDL subfraction more effectively. Two anti-apo $\mathbf{E}$ monoclonal antibodies and a polyclonal anti-apo $\mathbf{E}$ antibody inhibited cell-mediated degradation of and lipoprotein-dependent cholesterol esterification by $V_{L D L}$ but not $V_{2 D L}$ or LDL. The results suggest that receptor recognition sites on apo $E$ in preference to sites on apo $B$ mediate the cellular binding of hypertriglyceridemic $V_{L D L}$. However, the proportion of particles bound via apo $B$ seems to increase as VLDL decreases in size toward LDL, and virtually all of LDL binding is mediated by apo $B$.
\end{abstract}

\section{Introduction}

Very low density lipoproteins (VLDL)' isolated from plasmas of patients with hypertriglyceridemia seem to be taken up by normal cultured human fibroblasts much more readily than

Received for publication 2 September 1983 and in revised form 15 October 1984.

1. Abbreviations used in this paper: apo B, apolipoprotein B; apo E, apolipoprotein E; Fab, antigen-binding fragment; HTG, hypertriglyceridemic; TMU, tetramethylurea.

J. Clin. Invest.

(C) The American Society for Clinical Investigation, Inc.

0021-9738/85/02/0361/09 \$1.00

Volume 75, February 1985, 361-369
VLDL isolated from normal plasma $(1,2)$. Density gradient ultracentrifugation can be used to subfractionate $\operatorname{VLDL}(3,4)$, and it seems that differences between the cell reactivities of normal and hypertriglyceridemic (HTG) VLDL are most readily apparent when the largest particles, $S_{f}>100$, or $\mathrm{VLDL}_{1}$ fractions are compared (5). The cellular uptake of the $\mathrm{VLDL}_{1}$ fraction, which contains both apo $B$ and apo $E(6-8)$, is mediated by the same apo B,E receptor on fibroblasts (9-12) that recognizes low density lipoprotein (LDL) (13), which contains only apo B (13-15). Therefore, it was of great interest when Gianturco et al. (16) recently reported that the recognition of HTG-VLDL 1 by fibroblasts occurred via apo $E$ rather than apo B. Gianturco et al. (16) reached this conclusion by showing that thrombin digestion of $\mathrm{VLDL}_{1}$ abolished its cellular recognition. Concomitantly, $\mathrm{VLDL}_{1}$-apo $\mathrm{E}$ was cleaved into two major 22,000- and 12,000-mol wt peptides. Similar treatment of LDL had no effect on its recognition by cells. Furthermore, addition of intact apo $E$ to thrombin-treated $\mathrm{VLDL}_{1}$ restored its capacity to interact with cells, and addition of apo $E$ to $\mathrm{VLDL}_{1}$ isolated from normolipidemic subjects increased its recognition by cells.

We also have been interested in the interaction of apo Bcontaining lipoproteins with cultured cells (17-19), and have developed mouse monoclonal anti-human LDL antibodies as probes of lipoprotein-apo B structure and as inhibitors of lipoprotein-cell interactions. Two monoclonal IgG antibodies, $2 a$ and $2 b$, have been reported with the following characteristics: $a$ ) both antibodies $2 \mathrm{a}$ and $2 \mathrm{~b}$ and the antigen-binding fragment (Fab) of antibody $2 \mathrm{a}$ effectively block the apo B,E receptormediated binding and degradation of ${ }^{125} \mathrm{I}-\mathrm{LDL}$ in cultured normal human fibroblasts, while other anti-apo B antibodies do not inhibit cellular binding $(18) ; b$ ) chemical modification of the lysyl and arginsyl residues of LDL destroys the recognition of LDL by antibodies $2 \mathrm{a}$ and $2 \mathrm{~b}$, and also by fibroblasts (18); c) limited proteolysis of LDL destroys the immunoreactivities of the LDL cores vis-a-vis several monoclonal antibodies, but the abilities of the LDL cores to bind to antibodies $2 \mathrm{a}$ and $2 \mathrm{~b}$ and to fibroblast LDL receptors are preserved (19); and $d$ ) LDL of other species of animals bind to antibodies $2 a$ and $2 b$, but not to other antibodies (20). From these findings, we conclude that antibodies $2 \mathrm{a}$ and $2 \mathrm{~b}$ define epitopes on apo $\mathrm{B}$ that are closely related to the cell recognition domains on apo B. Apo E either in its delipidated form or reconstituted in dimyristoylphosphatidylcholine vesicles does not react with antibodies $2 \mathrm{a}$ and $2 \mathrm{~b}$ (G. Schonfeld, unpublished observations). Anti-human apo $\mathrm{E}$ monoclonal antibodies have also been developed in this laboratory. Two of these antibodies, 1506 A1.4 and 1907 F6.4, were used in the present study in an attempt to block apo E-mediated cell binding.

In the experiments to be reported, the apo $B$ and apo $E$ antibodies were used to inhibit the cell recognition of VLDL subfractions and LDL, to assess the roles of apo B and apo E 
in the binding of these lipoproteins to fibroblasts. We conclude that apo B plays a very small role compared with apo $E$ in the cellular binding of the largest VLDL fractions, $\mathrm{VLDL}_{1}$, but that the binding of progressively increasing proportions of the smaller and more dense VLDL fractions is mediated by apo $B$ and not apo $E$, and that nearly all of $L D L$ is recognized via apo B.

\section{Methods}

Lipoprotein donors. Lipoproteins of six subjects with hypertriglyceridemia and six normal controls were studied. Clinical characteristics are given in Table I. Lipoprotein lipid values are representative of those obtained for each subject at diagnosis. Patients were not taking medications and none had visible chylomicronemia.

Isolation of lipoproteins. Blood collected in 0.1\% EDTA was obtained from subjects after 12-14 h of fasting. After separation of cells by centrifugation, $10 \mu \mathrm{M}$ phenylmethylsulfonyl fluoride, $50 \mathrm{mg} / \mathrm{l}$ chloramphenicol and $50 \mathrm{mg} / \mathrm{l}$ gentamycin were added to the plasma $(16,21)$. VLDL was immediately isolated by ultracentrifugation at $d$ $=1.006$. LDL was isolated between the densities of 1.019 and 1.050 (22). Two ultracentrifugations were carried out at each density. VLDL density subfractions were isolated from VLDL that had been centrifuged only once, by zonal ultracentrifugation using a linear density gradient of $1.00-1.15 \mathrm{~g} / \mathrm{ml}(17,23)$. The fastest floating fraction $\left(\mathrm{S}_{\mathrm{f}} 120-400\right)$ was designated fraction $\mathrm{VLDL}_{1}$; the $\mathrm{S}_{6} 60-120$ fraction, $\mathrm{VLDL}_{2}$; and $\mathrm{S}_{\mathrm{f}}$ 20-60 fraction, $\mathrm{VLDL}_{3}$. On occasion, VLDL fractions were obtained by ultracentrifugation in a salt gradient formed in an SW40 swinging bucket rotor (3). After dialysis against $0.15 \mathrm{M}$ sodium chloride and 1 mM EDTA ( $\mathrm{pH}$ 8.2), the lipoproteins were concentrated by dry analysis (Aquacide IIA; Calbiochem-Behring Corp., American Hoechst Corp., San Diego, CA), dialyzed against EDTA-saline, filtered through 0.45- $\mu \mathrm{m}$ filters (Acrodisc; Gelman Sciences, Inc., Ann Arbor, MI), and stored in EDTA-saline containing the above mentioned concentrations of antibacterial agents at $4^{\circ} \mathrm{C}$.

The purities of the isolated VLDL and LDL preparations were assessed by $3-10 \%$ or $3-20 \%$ sodium dodecyl sulfate polyacrylamide gradient gel electrophoresis of the individual samples (24). VLDL apo $B / E$ ratios were calculated from these gels in some experiments. In LDL, three bands corresponding to apo B-100, B-74, and B-26 (8) were found by Coomassie Blue staining, but none of the LDL samples contained detectable amounts of B-48, serum albumin, or non-apo B apolipoproteins (21). The HTG-VLDL preparations used in the studies reported here contained apo B-100, trace amounts of apo B-48 and B26 (Fig. 1), apo E, and apolipoprotein C. The apo B contents of the VLDL subfractions and LDL were determined by tetramethylurea (TMU) precipitation (8). Apo E contents were quantitated by radioimmunoassay (RIA) after pretreatment of the VLDL with $6 \mathrm{M}$ urea (25). Total protein contents were measured by modifications of the method of Lowry et al. $(26,27)$.

Preparation of purified antibodies and Fab fragments. Affinity purified human apo B monoclonal antibodies and Fab fragments were prepared as previously described (18). The purity of the Fab fragments was checked by sodium dodecyl sulfate gel electrophoresis in the presence of $1 \% 2$-mercaptoethanol $\left(100^{\circ} \mathrm{C}\right.$ for $\left.2 \mathrm{~min}\right)$, which yielded two bands of 26,500 and 25,000 apparent molecular weight. The antiapo $B$ antibodies used in the present study are $464 B_{1} B_{3}(2 a)$ and $464 B_{1} B_{6}(2 b)$, which inhibit binding of $L D L$ to receptors and also define closely related but not identical epitopes $2 \mathrm{a}$ and $2 \mathrm{~b}$. Antibodies $457 C_{4} D_{1}$ (1a), and 467D3D5 (6), which do not inhibit LDL binding and define two other spatially independent epitopes called la and 6, were also used as controls.

Monoclonal antibodies were raised against human apo E. The details of their preparation are described elsewhere (Krul, E. S., M. J. Tikkanen, and G. Schonfeld, manuscript in preparation). The antiapo $\mathrm{E}$ monoclonal IgG fraction of ascitic fluid was purified by chromatography on either DEAE Affi-Gel Blue (Bio-Rad Laboratories, Richmond, CA) (28) or Protein-A Sepharose (Pharmacia Fine Chemicals, Piscataway, NJ) (29). The apo E antibodies used in the present study are $1506 \mathrm{Al} .4,1907 \mathrm{~F} 6.4$, and $1363 \mathrm{C} 3 \mathrm{~A} 10$, and are all of the $\mathrm{IgG}_{1}$ subclass. Six IgM antibodies were also used $(827,1365$, and 1366 series).

Polyclonal anti-human apo E antiserum (R224-3) was produced in rabbits (25) and the IgG was purified by ion exchange chromatography on cellulose (DE52; Whatman Chemical Separation, Inc., Clifton, NJ). Nonimmune immunoglobulins were isolated from nonimmunized mouse serum by $\left(\mathrm{NH}_{4}\right)_{2} \mathrm{SO}_{4}$ precipitation (20-40\% of saturation), followed by chromatography on Protein-A Sepharose (29).

${ }^{125}$ I-labeling of lipoproteins and antibodies. VLDL fractions and LDL used in the cell assays were ${ }^{125}$ I-labeled to a specific activity of $\sim 100 \mathrm{cpm} / \mathrm{ng}$ using the iodine monochloride method $(30,31) .>90 \%$ of the ${ }^{125}$ I-lipoproteins were precipitable by $10 \%$ TCA. The lipid solvent (chloroform/methanol, 2:1 vol/vol) extractable counts for ${ }^{125} \mathrm{I}-\mathrm{VLDL}$ were $9-17 \%$, and for ${ }^{125}$ I-LDL, were $7-9 \%$.

Table I. Lipoprotein Donors

\begin{tabular}{|c|c|c|c|c|c|c|c|c|c|}
\hline \multirow[b]{2}{*}{ Subject } & \multirow[b]{2}{*}{ Age } & \multirow{2}{*}{$\begin{array}{l}\text { Sex } \\
(M / F)\end{array}$} & \multirow[b]{2}{*}{ Height } & \multirow[b]{2}{*}{$\mathbf{W t}$} & \multicolumn{5}{|c|}{ Lipoprotein lipids } \\
\hline & & & & & TG & TC & VLDL-C & LDL-C & HDL-C \\
\hline & $y r$ & & $\mathrm{~cm}$ & $k g$ & $m g / d l$ & & & & \\
\hline 1 & 54 & $\mathbf{M}$ & 188 & 128 & 1,207 & 348 & 288 & 75 & 28 \\
\hline 2 & 41 & $\mathrm{~F}$ & 166 & 66 & 1,413 & 280 & 190 & 32 & 16 \\
\hline 3 & 54 & $\mathbf{F}$ & 164 & 49 & 3,648 & 729 & 672 & 49 & 24 \\
\hline 4 & 62 & $\mathrm{~F}$ & 166 & 65 & 694 & 319 & 199 & 83 & 37 \\
\hline 5 & 29 & $\mathbf{M}$ & 173 & 69 & 754 & 220 & 119 & 91 & 25 \\
\hline 6 & 44 & $\mathbf{M}$ & 182 & 82 & 475 & 239 & 85 & 123 & 32 \\
\hline 7 & 44 & $\mathrm{~F}$ & 178 & 61 & 143 & 239 & 29 & 125 & 85 \\
\hline 8 & 28 & $F$ & 165 & 52 & 90 & 176 & 18 & 95 & 63 \\
\hline 9 & 26 & $F$ & 170 & 61 & 76 & 181 & 15 & 111 & 55 \\
\hline 10 & 35 & $\mathbf{M}$ & 170 & 69 & 75 & 219 & 19 & 158 & 42 \\
\hline 11 & 34 & $\mathbf{M}$ & 173 & 66 & 105 & 168 & 21 & 109 & 38 \\
\hline 12 & 38 & $\mathbf{M}$ & 168 & 71 & 232 & 190 & 46 & 91 & 53 \\
\hline
\end{tabular}

TG, triglycerides; TC, total cholesterol; VLDL-C, LDL-C, and HDL-C, cholesterol in respective lipoproteins. 


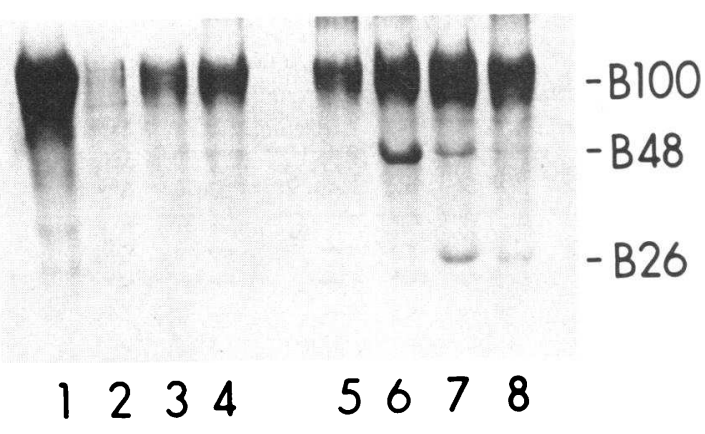

Figure 1. Apo B of VLDL preparations analyzed by 3-10\% polyacrylamide gradient gel electrophoresis and stained by Coomassie Blue. Lanes from left to right are: $1, \mathrm{LDL} ; 2, \mathrm{VLDL}_{1} ; 3, \mathrm{VLDL}_{2}$; and $4, \mathrm{VLDL}_{3}$ of HTG subject $5 ; 5$, VLDL $(d<1.006)$ of control subject 10; 6 and 7, VLDLs of two subjects with type III $\left(E_{2} / E_{2}\right)$ hyperlipoproteinemia (shown for comparison); 8, VLDL $(d<1.006)$ of HTG subject 4.

Human fibroblast cultures. Monolayer cultures of normal human skin fibroblasts were grown and maintained as previously described $(32,33)$. $\sim 7.5-10.0 \times 10^{4}$ cells were seeded into $35 \times 15-\mathrm{mm}$ dishes (Costar, Cambridge, MA) with Eagle's Modified Essential Medium ( $15 \%$ newborn calf serum). After $5 \mathrm{~d}$, the cells were washed with saline and the medium was replaced with medium containing $10 \%$ lipoproteindeficient human serum for $\mathbf{4 8} \mathrm{h}$.

Binding and degradation studies. Fibroblasts were grown in dishes as described above and experiments begun after growth for $48 \mathrm{~h}$ in medium containing lipoprotein-deficient serum. Experiments with antibodies were conducted in two ways. In some experiments, the medium was removed from each cell dish and replaced with medium containing the indicated amounts of purified antibodies, followed 5 min later by ${ }^{125}$ I-labeled lipoproteins $\left(\mathrm{VLDL}_{1}, \mathrm{VLDL}_{2}, \mathrm{VLDL}_{3}\right.$, or LDL) (18). Alternatively, lipoproteins were incubated with the indicated concentrations of purified antibodies for $30 \mathrm{~min}$ at $37^{\circ} \mathrm{C}$ before being added to the cells. Incubations of lipoproteins with cells were carried out at $37^{\circ} \mathrm{C}$ for $4 \mathrm{~h}$ in duplicate or triplicate dishes. The proteolytic degradation of ${ }^{125} \mathrm{I}$-lipoproteins by the fibroblasts was determined by measuring the TCA-soluble material in the spent medium after removal of free iodide with chloroform $(32,33)$. At the end of the incubations, the cells were washed as described (33), dissolved in $0.1 \mathrm{M}$ sodium hydroxide, and aliquots were taken for determination of cell protein and cell-associated radioactivity (binding). Nonspecific degradation in the absence of cells was determined in no-cell control dishes that had been precoated with the incubation medium. Binding and degradation were also determined in the presence of 20 -fold excesses of nonlabeled homologous lipoproteins. 20-fold of nonlabeled LDL also were added together with the different ${ }^{125}$ I-labeled lipoprotein fractions in some experiments. Results are expressed as nanograms of ${ }^{125}$ I-labeled lipoprotein bound or degraded per milligram of cell protein. In one experiment, various nonlabeled lipoproteins were assessed for their abilities to compete with ${ }^{125}$ I-labeled LDL for binding to the fibroblasts at $4^{\circ} \mathrm{C}$. Experiments were essentially carried out as described above with the medium containing $25 \mathrm{~mm}$ Hepes as buffering agent. Increasing concentrations of nonlabeled lipoproteins were added to the cells followed $5 \mathrm{~min}$ later by ${ }^{125}$ I-labeled lipoproteins.

Incorporation of $\left[{ }^{3} \mathrm{H}\right]$ oleate into cellular cholesteryl oleate. Indicated concentrations of lipoproteins were incubated with cultured fibroblasts for $5 \mathrm{~h}$ before the addition of $\left[{ }^{3} \mathrm{H}\right]$ oleic acid $(0.14 \mathrm{mM}, 20-40 \mathrm{cpm} /$ pmol) bound to defatted bovine serum albumin (BSA). After an additional $18 \mathrm{~h}$, the cells were washed three times with saline, scraped off the dishes, and aliquots were taken for protein determination. The concentration of intracellular cholesteryl $\left[{ }^{3} \mathrm{H}\right]$ oleate was determined by thin layer chromatography as described $(34,35)$.

Chromatography of VLDL on monoclonal antibody affinity column.
Monoclonal antibodies were coupled to $\mathrm{CNBr}$-activated Sepharose (Pharmacia Fine Chemicals, Piscataway, NJ) according to the directions of the manufacturer. Specifically, IgG from $2.5 \mathrm{ml}$ of ascites fluid (antibody $2 \mathrm{~b}$ ) was precipitated with $50 \%\left(\mathrm{NH}_{4}\right) \mathrm{SO}_{4}$. The precipitate was dissolved in protein coupling buffer $\left(0.1 \mathrm{M} \mathrm{NaHCO}_{3}, 0.5 \mathrm{M} \mathrm{NaCl}\right.$, $\mathrm{pH}$ 8.3) and incubated with $\sim 3.5 \mathrm{ml}$ of $\mathrm{CNBr}$-activated Sepharose gel for $2 \mathrm{~h}$ at room temperature with gentle shaking. Remaining active

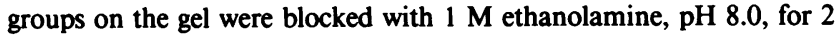
$\mathrm{h}$ at room temperature. The gel was washed with $0.1 \mathrm{M}$ sodium acetate

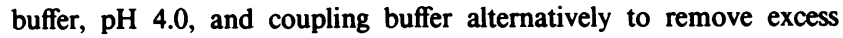
absorbed protein. The gel was finally washed with $0.01 \mathrm{M}$ phosphatebuffered saline (PBS), pH 7.2, buffer and stored in the same buffer containing antibiotics at $4^{\circ} \mathrm{C}$.

Radioiodinated lipoproteins ( $2.5 \times 10^{6} \mathrm{cpm}, 20-50 \mu \mathrm{g}$ total protein) were loaded onto the column in $3 \%$ BSA-PBS, pH 7.2, and left at $4^{\circ} \mathrm{C}$ overnight. The column was then eluted and washed with several gel bed volumes of PBS. 2-ml fractions were collected. Specifically bound proteins were eluted with $6 \mathrm{M}$ thiocyanate, $10 \mathrm{~mm}$ Tris, $\mathrm{pH} \mathrm{7.2,}$ followed by regeneration of the column with extensive washings with PBS. Aliquots of column fractions were counted for ${ }^{125}$ I-radioactivity.

\section{Results}

Stimulation of cholesterol esterification by various VLDL preparations. Initially, the abilities of various VLDL $(d<1.006)$ preparations isolated from normolipidemic and hyperlipidemic subjects to esterify cholesterol with $\left[{ }^{3} \mathrm{H}\right]$ oleate were examined. At equivalent VLDL protein concentrations $(25 \mu \mathrm{g} / \mathrm{ml})$ in the medium, HTG-VLDL stimulated esterification more effectively than normal VLDL. The values were $2.03 \pm 0.41$ and $0.50 \pm 0.12$ nmol cholesteryl ester formed per milligram cell protein per $18 \mathrm{~h}$ for HTG-VLDL (subjects $1-4$ ) and normal VLDL (subjects $7-12)$, respectively $(P<0.001)$. HTG-VLDL also contained more cholesterol per mass of protein (cholesterol/protein ratios were $1.63 \pm 0.25$ vs. $0.88 \pm 0.34$ for HTG and normal VLDL, respectively $(P<0.01)$. A positive correlation $(r=0.81)$ was obtained between nanomoles of cholesterol esterified and the lipoprotein cholesterol/protein ratio for the four HTG and five normolipidemic VLDLs added at equivalent protein doses. In one experiment, the apo $\mathrm{B} / \mathrm{apo} \mathrm{E}$ ratios were determined by scanning densitometry after electrophoresis of the HTG and normal VLDL protein on $3-20 \%$ polyacrylamide gels. The HTG-VLDL contained proportionately more apo $E$ than normal VLDL, and apo B/apo E ratios were $2.4 \pm 1.5$ vs. $5.0 \pm 1.2$, respectively, $P<0.01$. Interestingly, the cholesterol esterification rate was inversely correlated with the VLDL apo B/apo E ratio $(r=-0.77, n=8)$. These results are compatible with those reported by Gianturco et al. (1) and suggest that HTGVLDL in general are more potent in stimulating cholesterol esterification than are normal VLDL, and that apo E may be important in mediating the interaction of lipoproteins with cells. However, these experiments did not explain whether differences between HTG-VLDL and normal VLDL may be due to differences in the size and/or density distributions of VLDL subpopulations. Therefore, VLDL subfractions were examined.

Inhibition by anti-apo $B$ antibodies and Fab fragments of the interaction of VLDL subfractions and $L D L$ with cultured human fibroblasts. To ascertain the antibody dosage required to obtain maximum inhibition, increasing amounts of antibody $2 \mathrm{~b}$ were added to dishes containing $25 \mu \mathrm{g} / \mathrm{ml}$ of each VLDL subfraction and of LDL (Fig. 2). Maximum inhibition was achieved at $10 \mu \mathrm{g} / \mathrm{ml}$ of antibody for all VLDL and LDL 


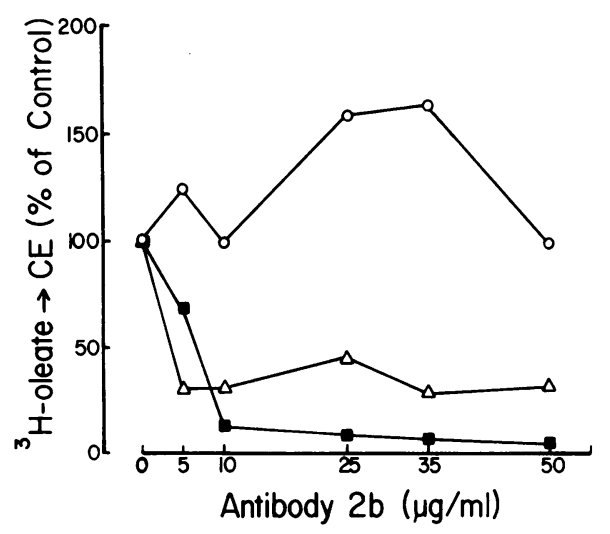

Figure 2. Inhibition by monoclonal anti-apo B antibody $2 \mathrm{~b}$ of lipoprotein-dependent esterification of cholesterol in cultured human fibroblasts. Lipoproteins were isolated from the plasma of HTG subject 5 and VLDL subfractions were prepared by zonal ultracentrifugation. Increasing doses of antibody $2 \mathrm{~b}$ were incubated with $25 \mu \mathrm{g} / \mathrm{ml}$ of lipoprotein for $30 \mathrm{~min}$ at $37^{\circ} \mathrm{C}$ before being added to the cells. The basal rate of cholesterol esterification (CE) for the fibroblasts was $0.27 \pm 0.05 \mathrm{nmol} \mathrm{CE} / \mathrm{mg}$ cell protein $/ 18 \mathrm{~h}$. Net uninhibited esterification rates for $V_{L D L}, V_{1} L_{3}$, and $L D L$ were $1.32,1.56$, and 10.8 $\mathrm{nmol} \mathrm{CE} / \mathrm{mg}$ cell protein $/ 18 \mathrm{~h}$, respectively. Mean coefficient of variation was $12 \%$ for each point in duplicate dishes. $-\mathrm{O}$,

$\mathrm{VLDL}_{1} ;-\Delta-, \mathrm{VLDL}_{3} ;-\square-, \mathrm{LDL}$.

fractions. Antibody $2 \mathrm{~b}$ inhibited LDL-stimulated cholesterol esterification by $\sim 90 \%$ (18). $\mathrm{VLDL}_{1}$-stimulated esterification was not inhibited, while stimulation by $\mathrm{VLDL}_{3}$ was inhibited by $70 \%$. In agreement with the above, when in other experiments $10-25 \mu \mathrm{g} / \mathrm{ml}$ of lipoprotein proteins were incubated with 25 and $50 \mu \mathrm{g} / \mathrm{ml}$ of antibodies $2 \mathrm{a}, 2 \mathrm{~b}$, or Fab fragments of $2 a$ (to ensure saturation of antibody binding sites on the lipoprotein particles), the binding and degradation by normal human fibroblasts of ${ }^{125} \mathrm{I}_{-} \mathrm{VLDL}_{1},{ }^{125} \mathrm{I}_{-} \mathrm{VLDL}_{2},{ }^{125} \mathrm{I}_{-} \mathrm{VLDL}_{3}$, and ${ }^{125} \mathrm{I}-\mathrm{LDL}$ were inhibited least for ${ }^{125} \mathrm{I}_{-} \mathrm{VLDL}_{1}$ and most for ${ }^{125} \mathrm{I}-\mathrm{LDL}$ (Table II and Fig. 3). The same antibodies and Fab fragments also inhibited cholesterol esterification dependent on $\mathrm{VLDL}_{3}$ by $35-73 \%$, on $\mathrm{VLDL}_{2}$ by $<5-32 \%$, and on $\mathrm{VLDL}_{1}$ by $<5-12 \%$ (Table II). The action of whole VLDL was inhibited by $33 \%$. Preincubations of antibody with lipoproteins for 30 min yielded the same results as when no premixing or $5 \mathrm{~min}$ of premixing were employed. These results suggest that the lipoproteins were saturated with antibodies or Fab under the experimental conditions employed, i.e., that any lack of antibody-induced inhibition of lipoprotein-cell interactions was not due to lack of opportunity for maximal antibodylipoprotein interaction. Antibodies $1 \mathrm{a}$ and 6 , which were previously shown (18) to be much less effective in inhibiting the cellular processing of ${ }^{125} \mathrm{I}-\mathrm{LDL}$, were much less effective inhibitors here, too, with all lipoprotein fractions. The Ig fraction of nonimmune mouse serum did not inhibit at all.

Incubations of fibroblasts in the presence of normolipidemic lipoproteins and antibodies were also carried out (Fig. $4 \mathrm{~A}-$ $C)$. Stimulation of cholesterol esterification by these VLDL subfractions was minimal (over the basal rates), suggesting that differences in size and/or density distributions between HTGVLDL and normal VLDL did not account for the differences in their interactions with cells. However, $\mathrm{VLDL}_{3}$ tended to stimulate better than $\mathrm{VLDL}_{1}$ or $\mathrm{VLDL}_{2}$. This may be due to the presence of IDL in $\mathrm{VLDL}_{3}$ as shown by Gianturco et al.
Table II. Inhibition by Antibodies of Lipoprotein Dependent Cholesterol Esterification

\begin{tabular}{|c|c|c|c|c|c|c|}
\hline \multirow{2}{*}{$\begin{array}{l}\text { Added } \\
\text { lipoprotein }\end{array}$} & \multicolumn{3}{|c|}{ Experiment 1} & \multicolumn{2}{|c|}{ Experiment 2} & \multirow{2}{*}{$\begin{array}{l}\text { Experiment } 3 \\
\text { Aby } 2 \mathrm{a}\end{array}$} \\
\hline & Aby $2 b^{*}$ & Fab 2a & Irtł & Aby $2 b$ & Aby 6 & \\
\hline VLDL $_{1}$ & $<5$ & 12 & $<5$ & - & - & $<5$ \\
\hline $\mathrm{VLDL}_{2}$ & $<5$ & $<5$ & $<5$ & - & - & $<5$ \\
\hline $\mathrm{VLDL}_{3}$ & 73 & 54 & $<5$ & - & - & 62 \\
\hline Whole VLDL & - & - & - & 33 & 3 & - \\
\hline LDL & 86 & 92 & $<5$ & 82 & 26 & 95 \\
\hline
\end{tabular}

Basal esterification $\left(\left[{ }^{3} \mathrm{H}\right]\right.$ oleate $\left.\rightarrow \mathrm{CE}\right)$ in the absence of lipoproteins was $0.45 \pm 0.05$ (Experiment $1, n=5$ ); $1.00 \pm 0.18$ (Experiment $2, n=4$ ); and $0.27 \pm 0.05$ (Experiment $3, n=12) \mathrm{nmol} / \mathrm{mg}$ protein/18 h (means $\pm \mathrm{SD}$ ). Control rates in the presence of $25 \mu \mathrm{g} / \mathrm{ml} \mathrm{VLDL}_{1}, \mathrm{VLDL}_{2}, \mathrm{VLDL}_{3}$, or LDL (subject 5), respectively, were 1.24, 1.08, 1.39, and 10.3 (Experiment 1), and 1.31, $1.05,1.55$, and 10.8 (Experiment 3). Rates in the presence of $25 \mu \mathrm{g} / \mathrm{ml}$ whole VLDL or LDL were 2.1 and 5.5 for Experiment 2. Basal rates have been subtracted from control rates to obtain uninhibited rates. Results are given as mean percent reduction of uninhibited rates produced by 25 and $50 \mu \mathrm{g}$ of antibody $2 \mathrm{~b}$ or $8.3 \mu \mathrm{g}$ and $16.7 \mu \mathrm{g} / \mathrm{ml} \mathrm{Fab}$ of antibody $2 \mathrm{a}$. The two doses each gave similar degrees of inhibition. In Experiment 1, antibodies 2b, Fab 2a, or Irr were added to cells 5 min before addition of lipoproteins. In Experiments 2 and 3 , antibodies $2 b, 6$, and $2 a$ were preincubated with lipoproteins for $30 \mathrm{~min}$ at $37^{\circ} \mathrm{C}$ before the mixture was added to the cell dishes. Each point was performed in duplicate dishes. Coefficients of variation were $<12 \%$.

* Aby, antibody.

¥ Irr, a nonimmune mouse IgG fraction purified on Staphylococcal Protein-A Sepharose CL4B, added at equivalent concentrations.

(1). Inhibiting effects of antibodies on the lipoprotein-dependent cholesterol esterification were difficult to discern in view of the low rates of stimulated esterification. However, where stimulation of esterification was appreciable (Fig. 4 B), antibody $2 b$ demonstrated inhibition similar to that observed for HTG$\mathrm{VLDL}_{3}$.

Inhibition by homologous VLDL subfractions and by $L D L$ of the cellular interactions of ${ }^{125} I-V L D L$ subfractions and of ${ }^{125} I-L D L$. Each VLDL subfraction was able to inhibit the cellular degradation of its labeled homologue (Table III). Inhibition in the presence of 20-fold excesses of nonlabeled VLDL subfraction ranged from 40 to $64 \%$ (Table III). The relatively poorer ability of unlabeled $\mathrm{VLDL}_{1}$ to inhibit ${ }^{125} \mathrm{I}$ -

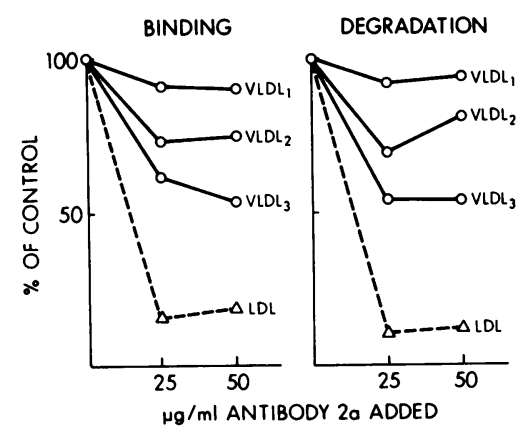

Figure 3. Inhibition of binding and degradation of ${ }^{125}$ I-labeled HTG$\mathrm{VLDL}_{1}, \mathrm{VLDL}_{2}$, and $\mathrm{VLDL}_{3}$ (each at $10 \mu \mathrm{g} / \mathrm{ml}$ medium) and of ${ }^{125} \mathrm{I}$-LDL $(5 \mu \mathrm{g} / \mathrm{ml})$ by antibody $2 \mathrm{a}$ in cultures of human fibroblasts. Lipoproteins were isolated from the plasma of subject 6 and VLDL subfractions were prepared by zonal ultracentrifugation. Respective $100 \%$ values (nanograms per milligram of cell protein) for binding were $121,122,215$, and 187 , and for degradation were 525, 224, 488, and 631 for $\mathrm{VLDL}_{1-3}$ and $\mathrm{LDL}$, respectively. Mean coefficient of variation was $<8 \%$ for duplicate dishes. 


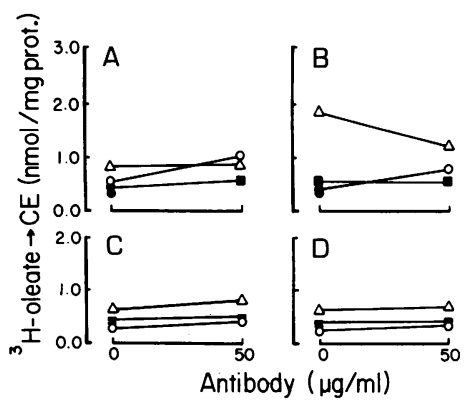
tracentrifugation in an SW40 rotor as described in Methods. Monoclonal antibodies $(50 \mu \mathrm{g} / \mathrm{ml})$ were incubated with $25 \mu \mathrm{g} / \mathrm{ml}$ of lipoprotein for $30 \mathrm{~min}$ at $37^{\circ} \mathrm{C}$ before being added to the cells. Apo B antibody $2 \mathrm{~b}$ was used in the experiments depicted in $A-C$, while apo $E$ antibody $1363 C 3 A 10$ was used in $D$. The basal rate of cholesterol esterification for the fibroblasts $(0.31 \pm 0.05, n=5)(\mathrm{nmol} \mathrm{CE} / \mathrm{mg}$ cell protein $/ 18 \mathrm{~h}$ ) is indicated by the solid circles. Mean coefficient of variation for points determined in duplicate dishes was $18 \%$. - 0 -, $\mathrm{VLDL}_{1} ;-\square-, \mathrm{VLDL}_{2} ;-\Delta-, \mathrm{VLDL}_{3} ;-\bullet-$, basal.

$\mathrm{VLDL}_{1}$ degradation is probably due to an exchange of radiolabeled apoproteins between the tracer and cold $\mathrm{VLDL}_{1}$ (16). As the percentage of TMU-soluble apoproteins decreases, i.e., $\mathrm{VLDL}_{2} \rightarrow \mathrm{VLDL}_{3}$ (22), the potential for exchange would diminish and could account for the increasing inhibiting effect of unlabeled $\mathrm{VLDL}_{2}$ and $\mathrm{VLDL}_{3}$ on tracer degradation.

In contrast with unlabeled VLDL used as inhibitors, 20fold excess of unlabeled LDL inhibited ${ }^{125} \mathrm{I}-\mathrm{VLDL}$ by $<5 \%$, ${ }^{125} \mathrm{I}_{-\mathrm{VLDL}}$ by only $9-27 \%$, and ${ }^{125} \mathrm{I}_{-\mathrm{VLDL}_{3}}$ by only $24-47 \%$, while LDL inhibited the degradation of ${ }^{125}$ I-LDL by $\sim 90 \%$. Thus, the patterns of inhibition produced by antibodies $2 \mathrm{a}$, $2 \mathrm{~b}$, and Fab fragments were similar to the patterns produced by excess unlabeled LDL.

To document that the VLDL cell interactions were occurring at the cellular LDL (apo B,E)-receptor, ${ }^{125} \mathrm{I}$-LDLs were incubated at $4^{\circ} \mathrm{C}$ in the presence of competing nonlabeled LDL and VLDL (Table IV). VLDL and LDL were equally
Table IV. Competition for Binding of ${ }^{125}$ I-LDL to Human Fibroblasts

\begin{tabular}{lll}
\hline Lipoprotein competitor & Cell associated & \\
\hline$\mu g / m l$ & $n g / m g$ cell protein & $\%$ of control \\
0 & 129 & 100 \\
FH-LDL & & \\
5 & 95 & 74 \\
10 & 71 & 55 \\
25 & 66 & 51 \\
100 & 40 & 31 \\
200 & 24 & 19 \\
Subject 4-VLDL & & \\
5 & 103 & 80 \\
25 & 64 & 49 \\
100 & 41 & 31 \\
\end{tabular}

${ }^{125} \mathrm{I}-\mathrm{LDL}(\mathrm{FH})$ at $5 \mu \mathrm{g} / \mathrm{ml}$ was added to all dishes along with the indicated concentrations of competitor lipoproteins. Incubations were for $2 \mathrm{~h}$ at $4^{\circ} \mathrm{C}$ and cell associated counts were determined. FH is a subject with homozygous familial hypercholesterolemia; 4 is an HTG subject (see Table I). VLDL $(d<1.006)$ from subject 4 was obtained by ultracentrifugation and washed by a second ultracentrifugation at $d$ 1.006. Results are means of triplicate dishes with coefficients of variation $<8 \%$.

potent, on a protein mass basis, in competing against ${ }^{125} \mathrm{I}-\mathrm{LDL}$ for occupancy of the LDL receptor, suggesting that the VLDLcell interactions indeed were occurring at that receptor.

Immunoaffinity chromatography. In previous work using monoclonal antibodies $2 a$ or $2 b$, the relative potencies of VLDL subfractions and LDL in competing against ${ }^{125} \mathrm{I}-\mathrm{LDL}$ for antibody binding was assessed in solid-phase plate assays (36). Competitive abilities of VLDL were inversely related to their sizes, i.e., $\mathrm{LDL}>\mathrm{VLDL}_{3}>\mathrm{VLDL}_{2}>\mathrm{VLDL}_{1}$. To confirm the results obtained with VLDL subfractions in the competitive RIAs, the VLDL subfractions and LDL of donor

Table III. Inhibition by Antibodies of ${ }^{125}$ I-Lipoprotein Degradation by Cultured Fibroblasts

\begin{tabular}{|c|c|c|c|c|c|c|c|c|c|}
\hline \multirow[b]{2}{*}{${ }^{125} \mathrm{I}$-tracers } & \multicolumn{3}{|l|}{ Subject 6} & \multicolumn{5}{|c|}{ Subject 5} & \multirow[b]{2}{*}{ VLDL } \\
\hline & Aby 2 ał & Aby la & LDL & Aby $2 a$ & Fab $2 a^{*}$ & Aby la & IrT§ & LDL & \\
\hline $\mathrm{VLDL}_{1}$ & 7 & 18 & $<5$ & 11 & $<5$ & $<5$ & $<5$ & $<5$ & $40 \pm 8$ \\
\hline $\mathrm{VLDL}_{2}$ & 25 & 22 & 9 & 32 & 28 & 20 & $<5$ & 27 & $50 \pm 19$ \\
\hline $\mathrm{VLDL}_{3}$ & 46 & 21 & 47 & 35 & 52 & 46 & $<5$ & 24 & $64 \pm 12$ \\
\hline LDL & 89 & $<5$ & 93 & 88 & 92 & 38 & $<5$ & 78 & - \\
\hline
\end{tabular}

Cells were grown in Eagle's minimal essential medium (MEM)-10\% LPDS for $48 \mathrm{~h}$ before experiments. To MEM-10\% LPDS were added $10 \mu \mathrm{g} /$ $\mathrm{ml}$ of the ${ }^{125} \mathrm{I}-\mathrm{VLDL}$ fractions or $5 \mu \mathrm{g} / \mathrm{ml}{ }^{125} \mathrm{I}-\mathrm{LDL}$ (see tracers) with the indicated inhibitors. Antibodies $2 \mathrm{a}, 1 \mathrm{a}$, or Irr $(25 \mu$ or $50 \mu \mathrm{g} / \mathrm{ml}) \mathrm{were}$ added to cells $5 \mathrm{~min}$ before addition of lipoproteins. To test effects of longer exposure of lipoproteins to antibody, Fab 2a and lipoproteins were mixed in a test tube in proportions as outlined and incubated at $37^{\circ} \mathrm{C}$ for $30 \mathrm{~min}$. The mixtures were then added to cell cultures. This experiment is indicated by an asterisk. Homologous VLDL subfractions (i.e., ${ }^{125} I-V_{L D L} \mathrm{Vs}_{1} \mathrm{VLDL}_{1} ;{ }^{125} \mathrm{I}_{-\mathrm{VLD}} \mathrm{VL}_{2}$ vs. VLDL $\mathrm{VL}_{2}$, etc.) or LDL (each in 20-fold excess of tracer) were added to test their effectiveness in inhibiting tracer uptake. Incubations with cells were for $4 \mathrm{~h}$ at $37^{\circ} \mathrm{C}$ for all ligands and inhibitors tested. Results are percent of inhibition produced by the various inhibitors. In the case of inhibition by homologous VLDL subfractions, percent \pm SEMs are given for 4 separate experiments with VLDLs from subjects $4(n=2)$, 5 , and 6 . Each point was performed in duplicate dishes with an average coefficient of variation of $<8 \%$. 100\% values for subject 6 were $525,224,448$, and $631 \mathrm{ng} / \mathrm{mg}$ cell protein for $\mathrm{VLDL}_{1}, \mathrm{VLDL}_{2}, \mathrm{VLDL}_{3}$, and $\mathrm{LDL}$, respectively. For subject 5, the values were 1,173, 756, 1,595, and $1,393 \mathrm{ng} / \mathrm{mg}$ cell protein. Nonspecific degradation has been subtracted from all values. $¥$ Aby, antibody. $\S$ Irr, a nonimmune mouse IgG fraction isolated from mouse serum on Staphylococcal Protein A Sepharose CL4B, added at equivalent doses. 
Table V. Binding of ${ }^{125}$ I-Lipoproteins to an Anti-LDL Immunoaffinity Column

\begin{tabular}{lll}
\hline${ }^{125}$ I-ligands & $\begin{array}{l}\text { Counts bound } \\
\text { to column }\end{array}$ & $\begin{array}{l}\text { Counts precipitable } \\
\text { by TMU }\end{array}$ \\
\hline & $\%$ & $\%$ \\
VLDL $(d<1.006)$ & 34 & 50 \\
VLDL $_{1}$ & 23 & 37 \\
VLDL $_{2}$ & 42 & 49 \\
VLDL $_{3}$ & 53 & 69 \\
LDL & 96 & 97 \\
HDL & $<0.5$ & $<0.1$
\end{tabular}

$\sim 2.5 \times 10^{6}$ of ${ }^{125}$ I-labeled lipoprotein (10-25 $\mu \mathrm{g}$ protein) of donor 5 were loaded in 3\% BSA-PBS buffer, pH 7.4, onto an immunoaffinity column containing monoclonal anti $\mathrm{LDL}$ antibody $2 \mathrm{~b}$ coupled to Sepharose 4B.

5 were iodinated and subjected to affinity chromatography on a column containing antibody $2 \mathrm{~b}$ (Table V). $23 \%$ of $\mathrm{VLDL}_{1}$, $53 \%$ of $\mathrm{VLDL}_{3}$, and $34 \%$ of the whole VLDL $(d<1.006)$ were bound. In control experiments, iodinated HDL was passed through the same column, and the ${ }^{125} \mathrm{I}-\mathrm{VLDL}$ fractions and ${ }^{125} \mathrm{I}-\mathrm{LDL}$ were also passed through a column containing no antibodies. Virtually all of ${ }^{125} \mathrm{I}-\mathrm{LDL}$, but none of ${ }^{125} \mathrm{I}-\mathrm{HDL}$, were bound to the antibody-containing column. $<1.0 \%$ of any of the lipoproteins was retained on the control column. To ascertain that there was no selective retention of apo $B$ on the column, the proportion of TMU-precipitable counts in the starting whole ${ }^{125} \mathrm{I}-\mathrm{VLDL}$ and in nonbound ${ }^{125} \mathrm{I}-\mathrm{VLDL}$ fractions were compared. They were found to be indistinguishable ( 50 and 53\%, respectively), suggesting that the apo B and non-apo B proteins of VLDL were not dissociated on the column. The retention of VLDL fractions by the column was similar to the rank order of competition potencies of the fractions in the competitive immunoassays. Also, the inhibition by antibody $2 \mathrm{~b}$ of VLDL-dependent cholesterol esterification was compatible with the affinity column data (Table II). The data strongly suggest that the expression of the $2 \mathrm{a}$ and $2 \mathrm{~b}$ epitopes on VLDL is inversely related to VLDL size.

Inhibition by anti-apo $E$ antibodies of the interaction of $V L D L$ and $L D L$ fractions with cultured human fibroblasts. Since a significant proportion of HTG-VLDL 1 and VLDL cellular uptake could not be inhibited by anti-apo $B$ antibodies $2 a$ or $2 b$, it followed that other apolipoproteins on the surface of these lipoproteins could be responsible for binding to cells. Therefore, antibodies directed against apo $\mathrm{E}$ were tested for their abilities to block VLDL-cell interactions (Figs. 5 and 6). Polyclonal anti-apo E antiserum (R224-3) inhibited binding (not shown) and degradation of $\mathrm{VLDL}_{1}$ by $\sim 25 \%$ (Fig. 6), and $V_{L D L}$-dependent cholesterol esterification by $\sim 45 \%$ (Fig. 5). On the other hand, $\mathrm{VLDL}_{3}$ was poorly inhibited if at all under the same conditions. Two anti-apo $\mathrm{E}$ monoclonal antibodies were even more effective inhibitors of $\mathrm{VLDL}_{1}$-cell interactions (Figs. 5 and $6, B$ and $C$ ). These antibodies did not inhibit $\mathrm{VLDL}_{3}$. Differences in apo $\mathrm{E}$ content of the VLDL fractions cannot account for the difference in antibody inhibition (Fig. 6), since $\mathrm{VLDL}_{3}$ generally has less apo $\mathrm{E}$ than $\mathrm{VLDL}_{1}$ and therefore antibody was clearly in excess. A third monoclonal anti-apo E antibody, $1363 \mathrm{C} 3 \mathrm{~A} 10$, did not prevent cellular uptake and processing of either normolipidemic (Fig. $4 D$ ) or HTG-VLDL subfractions (Figs. $5 D$ and $6 D$ ). Six other monoclonal IgM anti-apo $\mathrm{E}$ antibodies also were equally ineffective in inhibiting VLDL uptake (not shown).

Interestingly, in several cases the anti-apo $\mathrm{E}$ antibodies seemed to enhance the cellular processing of the HTG-VLDL 3 (Figs. 5 and 6). This effect may be due to a conformational change in the lipoprotein structure induced by antibodybinding to a determinant distant from the cellular recognition site (cooperativity) such that cellular uptake is enhanced. Another explanation of the enhanced uptake is the possible interaction of the antibody-VLDL 3 immune complex with a purported Fc receptor on human fibroblast (37). As the Fc receptor binds aggregated IgG or immune complexes preferentially over monomeric IgG, this may explain the increased stimulation of $\mathrm{VLDL}_{3}$ uptake at higher antibody/antigen ratios (Figs. 5 and 6).

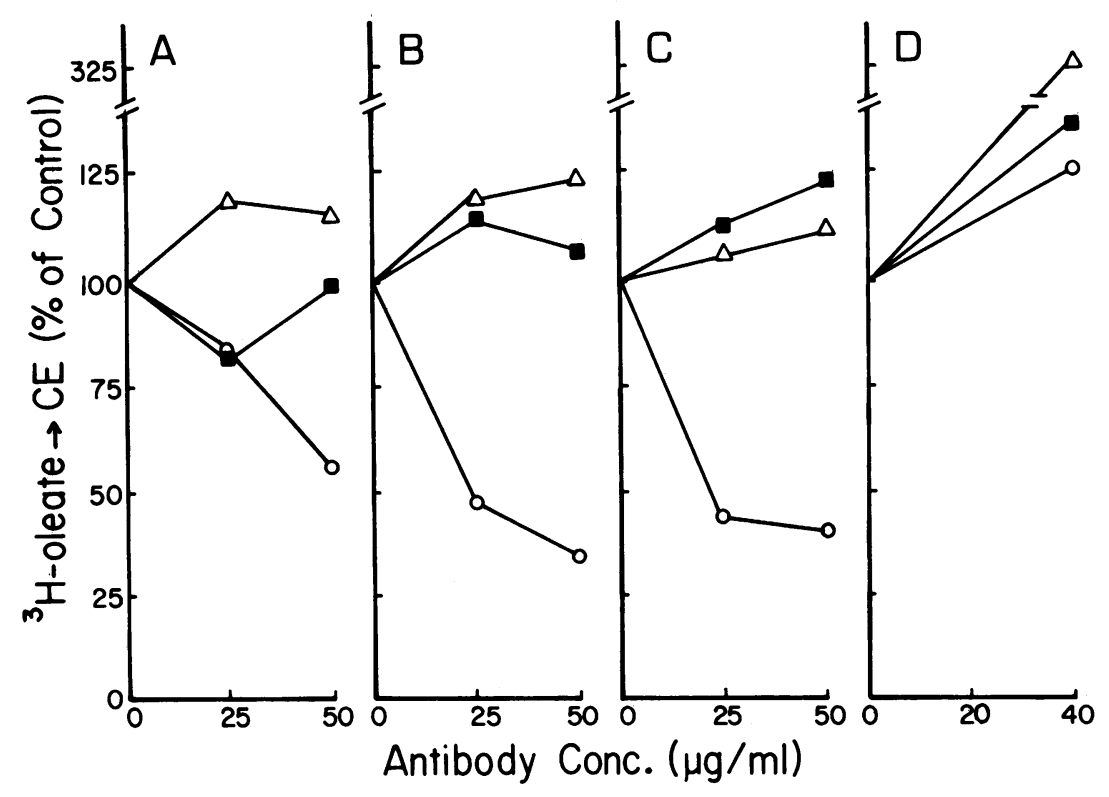

Figure 5. Inhibition by polyclonal or monoclonal anti-apo E antibodies of the HTG lipoproteindependent esterification of cholesterol in cultured human fibroblasts. Lipoproteins were isolated from HTG subject $5(A-C)$ or subject $4(D)$. Indicated doses of antibodies were incubated with $25 \mu \mathrm{g} / \mathrm{ml}(A-C)$ or $20 \mu \mathrm{g} / \mathrm{ml}$ lipoprotein $(D)$ for $30 \mathrm{~min}$ at $37^{\circ} \mathrm{C}$ before being added to the cells. Basal rates of cholesterol esterification of $0.48 \pm 0.09(n=3, A-C)$ and $0.31 \pm 0.05(n=5$, D) $\mathrm{nmol} \mathrm{CE} / \mathrm{mg}$ cell protein $/ 18 \mathrm{~h}$, respectively, have been subtracted to obtain net esterification rates in the presence of lipoproteins. In panels $A$ $C$, net rates for $\mathrm{VLDL}_{1}, \mathrm{VLDL}_{3}$, and $L D L$ were $1.12,1.02$, and 17.1. Respective net rates in $D$ were $0.27,1.18$, and $7.88 \mathrm{nmol} \mathrm{CE} / \mathrm{mg}$ cell protein $/ 18 \mathrm{~h}$. The following antibodies were used: $A$, polyclonal R224-3; $B$, monoclonal 1506 A1.4; $C$, monoclonal $1907 \mathrm{~F} 6.4$; and $D$, monoclonal 1363 C3A10. Mean coefficients of variation were $7 \%$ $(A-C)$ and $18 \%(D)$ for points determined in duplicate dishes. $-0-, \mathrm{VLDL}_{1} ;-\triangle-, \mathrm{VLDL}_{3}$; $-\square$, LDL. 


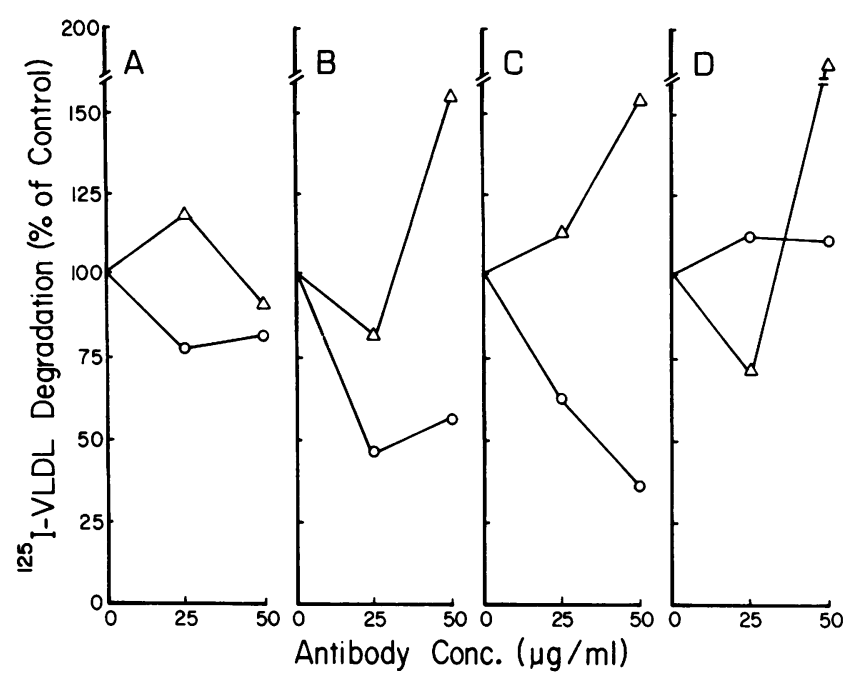

Figure 6. Inhibition by polyclonal or monoclonal anti-apo E antibodies of the degradation of ${ }^{125}$ I-lipoproteins by cultured human fibroblasts. VLDL subfractions were isolated from HTG subjects $5(A-C)$ or $4(D)$ and iodinated as described in Methods. Indicated doses of antibodies were incubated with $25 \mu \mathrm{g} / \mathrm{ml}$ of ${ }^{125} \mathrm{I}_{-} \mathrm{VLDL}_{1}$ or ${ }^{125} \mathrm{I}$ $\mathrm{VLDL}_{3}$ for $30 \mathrm{~min}$ at $37^{\circ} \mathrm{C}$ before being added to the cells. $100 \%$ values (nanograms per milligram of cell protein, $4 \mathrm{~h}$ ) for degradation of VLDL 1 and $\mathrm{VLDL}_{3}$ were 186 and 99 for $A-C$ and 745 and 68 for $D$. Mean coefficients of variation were $14 \%(A-C)$ and $8 \%(B)$ for points determined in duplicate dishes. The antibodies used are described in the legend to Fig. 5. VLDL-apo E contents were determined by conventional RIA. For $\mathrm{VLDL}_{1}$ and $\mathrm{VLDL}_{3}$ in $A-C$, apo $\mathrm{E}$ was $3.2 \%$ and $1.2 \%$ of total VLDL protein. In $D$ the values were 8.9\% and $2.7 \%$. $-0-, \mathrm{VLDL}_{1} ;-\triangle-, \mathrm{VLDL}_{3}$.

\section{Discussion}

Triglyceride-rich lipoproteins isolated from plasma are bound, internalized, and degraded by cultured fibroblasts and aortic smooth muscle cells via the LDL (apo B,E) receptor in a metabolic sequence that resembles the cellular processing of LDL (38). But not all VLDL or chylomicrons isolated from plasma seem to be taken up at identical rates. Chylomicrons and large VLDL particles are taken up more slowly than the smaller chylomicrons or VLDL remnants produced by lipoprotein lipase catalyzed lipolysis $(17,39)$. Larger $\alpha$-migrating VLDL isolated from plasmas of subjects with various forms of hypertriglyceridemia are taken up much more rapidly than seemingly similar $\alpha$-VLDL particles isolated under identical conditions from normal plasma $(2,16)$. $\beta$-VLDL induced by high fat, high carbohydrate diets are processed more rapidly than $\alpha$-VLDL (38). Presumably, all of these lipoprotein-cell interactions are mediated by apoproteins, but the alterations in lipoprotein-apoprotein structure responsible for the differences are not known.

Four general approaches have been used to ascertain which apoproteins play roles in the recognition of lipoproteins by cellular receptors; $a$ ) studies of interactions of apoprotein-lipid recombinants with cultured cells or perfused organs, $b$ ) studies of effects of alterations of compositions of hololipoproteins on cell interactions, $c$ ) studies of consequences of cleavage of apoproteins in lipoproteins on cell interactions, and $d$ ) studies relating immunologic activities of apoproteins to cellular binding. The role of apo $E$ in cell binding was recognized in experiments with apo E-phospholipid recombinants using both wild type $\left(E_{3}\right)$ and mutant $\left(E_{2}\right)$ forms of the protein (9-1i). The compositional approach provided information on the opposing roles of apo E and apolipoprotein CIII in VLDL binding $(40,41)$. Thrombin-induced cleavage of apo $E$ abolished the binding of large HTG-VLDL 1 to fibroblasts, implying that apo $\mathrm{E}$ mediates the interactions (16). The immunologic approach uncovered that the size of VLDL affects the dispositions of apo B on the surfaces of lipoproteins $(17,42-46)$ and also that the cellular binding of LDL can be inhibited only by selected monoclonal anti-LDL antibodies, i.e., many antibodies did not inhibit $(17,18,42)$. Therefore, it was possible to connect single epitopes of LDL with cellular binding.

In the present experiments, each of the HTG ${ }^{125} \mathrm{I}-\mathrm{VLDL}$ subfractions was appreciably taken up and degraded by the cultured normal fibroblasts, and each fraction also stimulated the esterification of $\left[{ }^{3} \mathrm{H}\right]$ oleate into cholesteryl-esters. Normal VLDL interacted much less effectively with cells. Antibodies $2 \mathrm{a}$ and $2 \mathrm{~b}$ and Fab $2 \mathrm{a}$ inhibited these processes in a progressive fashion, with inhibition increasing from $V_{L D L}$ to $V_{L D L}$ to $\mathrm{VLDL}_{3}$, and finally to LDL. A similar pattern of inhibition was produced by excess LDL. Antibodies la or 6 produced much less inhibition, and nonimmune mouse IgG produced none at all. Therefore, the inhibition by antibodies $2 a$ and $2 b$ was specific. The ability of Fab $2 a$ at equimolar doses to produce similar degrees of inhibition further confirms the specificity of the inhibition. Since lower doses of the inhibiting antibodies and Fab fragments than were used for most experiments were shown to inhibit to the same extent (Fig. 2), all available epitopes must have been saturated, yet some proportion of each VLDL subfraction was still taken up by the cells. If epitopes $2 a$ and $2 b$ are involved in cellular recognition and for the reasons enumerated in the Introduction, we believe they are, cellular recognition of VLDL must have occurred not only via apo B, but also at alternate domains, probably on apo E. This hypothesis was tested by incubating lipoproteins before their addition to cells with anti-apo $\mathrm{E}$ antibodies. The experiments clearly showed a preferential inhibition of $\mathrm{VLDL}_{1}$ uptake and cellular processing by these antibodies when compared with the smallest $\mathrm{VLDL}_{3}$ fraction. From the data, it seems that the size heterogeneity introduced either during VLDL catabolism (47) or during secretion of nascent VLDL particles (48) is accompanied by heterogeneity of cell binding characteristics. While the vast majority of the largest $\mathrm{VLDL}_{1}$ particles interacts with the apo B,E-receptor almost solely via apo $\mathrm{E}$, a progressively larger proportion of the smaller particles of $\mathrm{VLDL}_{2}$ and $\mathrm{VLDL}_{3}$ interact via apo $\mathrm{B}$, and the end product of the "cascade," LDL, interacts almost completely via apo B. Similar conclusions based on thrombin-induced proteolysis of apo $\mathrm{E}$ in VLDL subfractions have been reported in abstract form (49).

What accounts for the initial preference for apo $\mathrm{E}$ and the gradual changeover to apo $B$ ? Several possibilities exist. The relevant binding sites on apo $B$ may not be available on the largest VLDL, either because they are buried in lipid or are masked by other apoproteins. Alternatively, perhaps the domains are not masked, but the organization of apo B in larger VLDL is such that the appropriate domains interact with cellular receptors very weakly. The experiments in which the inhibition of ${ }^{125}$ I-lipoprotein binding to antibody $2 \mathrm{a}$, but not to antibody la, varied inversely with the flotation rate of VLDL (Table III), demonstrated that the expression of relevant regions of apo B vary with VLDL size and/or density. These 
results support the hypothesis that the disposition of apo B may play a role in the interaction of VLDL with cells. However, these experimental results do not distinguish whether the relevant domain is buried or weakly reactive for other reasons. Another possibility for the gradual changeover from apo $\mathrm{E}$ to apo B may be simply that there are more molecules of apo $E$ per particle on large than on small VLDL, and virtually none on LDL. This idea is supported by the observation that apo $\mathrm{E}$ contents of $\mathrm{VLDL}_{1}$ tend to be higher than those for $\mathrm{VLDL}_{3}$ (Krul, E. S., M. J. Tikkanen, and G. Schonfeld, manuscript in preparation) (Fig. 6), and by the direct relationship between binding of phospholipid vesicles to fibroblasts and the amounts of functional apo $\mathrm{E}$ associated with the vesicles $(10,11)$. The effective interactions of HTGVLDL with cells and the lack of such interactions by normal $\mathrm{VLDL}_{1}$ also may be due to the presence of greater amounts of apo $E$ on the former (50-52). A third alternative is that the conformation of apo $\mathrm{E}$ in $\mathrm{VLDL}_{1}$ favors cellular interaction but apo $\mathrm{E}$ conformations may change during lipolysis and catabolism of VLDL in an unfavorable direction. These three alternatives are not mutually exclusive, and one or more of them may be operating at the same time, but more work is needed to ascertain which are operative and to what extent.

\section{Acknowledgments}

The authors would like to thank Ratna Dargar and Barbara Pfleger for technical assistance, and Lois Weismantle of the Lipid Research Clinic for obtaining the blood donors. The typing of this manuscript by Phyllis Anderson is appreciated.

This work was supported by National Institutes of Health grant \#HL 15308 and the Mallinckrodt Hybridoma Contract. Dr. Krul is the recipient of a Fellowship of the Medical Research Council of Canada. Dr. Tikkanen was supported in part by a Fogarty International Fellowship, National Institutes of Health.

\section{References}

1. Gianturco, S. H., A. M. Gotto, Jr., R. L. Jackson, J. R. Patsch, H. D. Sybers, O. D. Taunton, D. L. Yeshurun, and L. C. Smith. 1978. Control of 3-Hydroxy-3-Methylglutaryl-CoA reductase activity in cultured human fibroblasts by very low density lipoproteins of subjects with hypertriglyceridemia. J. Clin. Invest. 61:320-328.

2. Gianturco, S. H., F. B. Brown, A. M. Gotto, Jr., and W. A. Bradley. 1982. Receptor-mediated uptake of hypertriglyceridemic very low density lipoproteins by normal human fibroblasts. J. Lipid Res. 23:984-993.

3. Lindgren, F. T., L. C. Jensen, and F. T. Hatch. 1972. The isolation and quantitative analysis of serum lipoproteins. In Blood Lipids and Lipoproteins: Quantitation, Composition, and Metabolism. G. J. Nelson, editor. John Wiley \& Sons Inc., New York. 181-274.

4. Patsch, W., J. R. Patsch, G. M. Kostner, S. Sailer, and H. Braunsteiner. 1978. Isolation of subfractions of human very low density lipoproteins by zonal ultracentrifugation. J. Biol. Chem. 253:49114915.

5. Gianturco, S. H., C. J. Packard, J. Shephers, L. C. Smith, A. L. Catapano, H. D. Sybers, and A. M. Gotto, Jr. 1980. Abnormal suppression of 3-hydroxy-3-methylglutaryl-CoA reductase activity in cultured human fibroblasts by hypertriglyceridemic very low density lipoprotein subclasses. Lipids. 15:456-463.

6. Shore, V. G., B. Shore, and R. G. Hart. 1974. Changes in apolipoproteins and properties of rabbit very low density lipoproteins on induction of cholesteremia. Biochemistry. 13:1579-1584.

7. Havel, R. J., and J. P. Kane. 1973. Primary dysbetalipoprotein- emia: predominance of a specific apoprotein species in triglyceriderich lipoproteins. Proc. Natl. Acad. Sci. USA. 70:2015-2019.

8. Kane, J. P., T. Sata, R. L. Hamilton, and R. J. Havel. 1975. Apoprotein composition of very low density lipoproteins of human serum. J. Clin. Invest. 56:1622-1634.

9. Innerarity, T., and R. W. Mahley. 1978. Enhanced binding by cultured human fibroblasts of apo-E-containing lipoproteins as compared with low density lipoproteins. Biochemistry. 17:1440-1447.

10. Pitas, R. E., T. L. Innerarity, K. S. Arnold, and R. W. Mahley. 1979. Rate and equilibrium constants for binding of apo-E-HDL $L_{c}(a$ cholesterol induced lipoprotein) and low density lipoproteins to human fibroblasts: evidence for multiple receptor binding of apo-E-HDL $\mathrm{L}_{\mathrm{c}}$. Proc. Natl. Acad. Sci. USA. 76:2311-2315.

11. Pitas, R. E., T. L. Innerarity, and R. W. Mahley. 1980. Cell surface receptor binding of phospholipid-protein complexes containing different ratios of receptor-active and inactive E apoprotein. J. Biol. Chem. 255:5454-5460.

12. Goldstein, J. L., R. G. W. Anderson, and M. S. Brown. 1979. Coated pits, coated vesicles, and receptor mediated endocytosis. Nature (Lond.). 279:679-685.

13. Shireman, R. B., and W. R. Fisher. 1979. Apolipoprotein B: its role in the control of fibroblast cholesterol biosynthesis and in the regulation of its own binding to cellular receptors. J. Lipid Res. 20:594-598.

14. Steele, J. C. H., Jr., and J. A. Reynolds: 1979. Characterization of the apolipoprotein B polypeptide of human plasma low density lipoprotein in detergent and denaturant solutions. J. Biol. Chem. 254:1633-1638.

15. Bradley, W. A., M. F. Rohde, and A. M. Gotto, Jr. 1980. Studies of the primary structure of apolipoprotein B. Lipoprotein Structure. Ann. NY Acad. Sci. 348:87-103.

16. Gianturco, S. H., A. M. Gotto, Jr., S.-L. Hwang, J. B. Karlin, A. H. Y. Lin, S. C. Prasad, and W. A. Bradley. 1983. Apolipoprotein E mediates uptake of Sf 100-400 hypertriglyceridemic very low density lipoproteins by the low density lipoprotein receptor pathway in normal human fibroblasts. J. Biol. Chem. 258:4526-4533.

17. Schonfeld, G., W. Patsch, B. Pfleger, J. L. Witztum, and S. W. Weidman. 1979. Lipolysis produces changes in the immunoreactivity and cell reactivity of very low density lipoproteins. J. Clin. Invest. 64:1288-1297.

18. Tikkanen, M. J., R. Dargar, B. Pfleger, B. Gonen, J. M. Davie, and G. Schonfeld. 1982. Antigenic mapping of human low density lipoprotein with monoclonal antibodies. J. Lipid Res. 23:1032-1038.

19. Hahm, K. S., M. J. Tikkanen, R. Dargar, T. G. Cole, J. M. Davie, and G. Schonfeld. 1983. Limited proteolysis selectively destroys epitopes on apolipoprotein B in low density lipoproteins. J. Lipid Res. 24:877-885

20. Nelson, C. A., M. A. Tasch, M. Tikkanen, R. Darger, and G. Schonfeld. 1984. Evolution of low density lipoprotein structure probed with monoclonal antibodies. J. Lipid Res. 25:821-830.

21. Kane, J. P., A. Hardman, and H. E. Paulus. 1980. Heterogeneity of apolipoprotein B: isolation of a new species from human chylomicrons. Proc. Natl. Acad. Sci. USA. 77:2465-2469.

22. Schonfeld, G., R. S. Lees, P. K. George, and B. Pfleger. 1974. Assay of total plasma apolipoprotein B concentration in human subjects. J. Clin. Invest. 53:1458-1467.

23. Patsch, W., J. R. Patsch, G. M. Kostner, S. Sailer, and H. Braunsteiner. 1978. Isolation of subfractions of human very low density lipoproteins by zonal ultracentrifugation. J. Biol. Chem. 253:49114915.

24. Swaney, J. B., and K. S. Kuehl. 1976. Separation of apolipoproteins by an acrylamide-gradient sodium dodecyl sulfate gel electrophoresis system. Biochim. Biophys. Acta. 446:561-565.

25. Falko, J. M., G. Schonfeld, J. L. Witztum, J. B. Kolar, S. W. Weidman, and R. Steelman. 1980. Effects of diet on apo-E levels and on the apo-E subspecies in human plasma lipoproteins. J. Clin. Endocrinol. Metab. 50:521-528.

26. Lowry, O. H., N. J. Rosebrough, A. L. Farr, and R. J. Randall. 
1951. Protein measurement with the Folin phenol reagent. J. Biol. Chem. 193:265-275.

27. Bensadoun, A., and D. Weinstein. 1976. Assay of proteins in the presence of interfering materials. Anal. Biochem. 70:241-250.

28. Bruck, C., D. Portetelle, C. Glineur, and A. Bollen. 1982. Onestep purification of mouse monoclonal antibodies from ascitic fluid by DEAE Affi-Gel Blue chromatography. J. Immunol. Methods. 53:313319.

29. Ey, P. L., S. J. Prowse, and C. R. Jenkin. 1978. Isolation of pure IgG, $\operatorname{IgG}_{2 a}$, and $\operatorname{IgG}_{2 b}$ immunoglobulins from mouse serum using Protein-A Sepharose. Immunochemistry. 15:429-436.

30. McFarlane, A. S. 1956. Labelling of plasma protein with radioactive iodine. Biochem. J. 62:135-143.

31. Bilheimer, D. W., S. Eisenberg, and R. I. Levy. 1972. The metabolism of very low density lipoprotein proteins I: preliminary in vitro and in vivo observations. Biochim. Biophys. Acta. 260:212-221.

32. Goldstein, J. L., and M. S. Brown. 1974. Binding and degradation of low density lipoproteins by cultured human fibroblasts. J. Biol. Chem. 249:5153-5162.

33. Ostlund, R. E., Jr., B. Pfleger, and G. Schonfeld. 1979. Role of microtubules in low density lipoproteins processing by cultured cells. J. Clin. Invest. 63:75-84.

34. Goldstein, J. L., S. E. Dana, and M. S. Brown. 1974. Esterification of low density lipoprotein cholesterol in human fibroblasts and its absence in homozygous familial hypercholesterolemia. Proc. Natl. Acad. Sci. USA. 71:4288-4292.

35. Gonen, B., J. Baenziger, G. Schonfeld, D. Jacobson, and P. Farrar. 1981. Non-enzymatic glycosylation of low density lipoprotein in vitro: effects on cell interactive properties. Diabetes. 30:575-578.

36. Tikkanen, M. J., T. G. Cole, K.-S. Hahm, E. S. Krul, and G. Schonfeld. 1983. Expression of apolipoprotein B epitopes in very low density lipoprotein subfractions: studies with monoclonal antibodies. Arteriosclerosis. 4:138-146.

37. Frey, J., and B. Einsfelder. 1984. Induction of surface IgG receptors in cytomegalovirus-infected human fibroblasts. Eur. J. Biochem. 138:213-216.

38. Mahley, R. W., and T. L. Innerarity. 1983. Lipoprotein receptors and cholesterol homeostasis. Biochim. Biophys. Acta. 737:197222.

39. Floren, C.-H., J. J. Albers, B. J. Kudchodkar, and E. L. Bierman. 1981. Receptor dependent uptake of human chylomicron remnants by cultured skin fibroblasts. J. Biol. Chem. 256:425-433.

40. Quarfordt, S. H., G. Michalopoulos, and B. Schirmer. 1982. The effect of human $\mathrm{C}$ apolipoproteins on the in vitro hepatic metabolism of triglyceride emulsions in the rat. J. Biol. Chem. 257:14642-14647.

41. Windler, E., Y.-S. Chao, and R. J. Havel. 1980. Determinants of hepatic uptake of the triglyceride-rich lipoproteins and their remnants in the rat. J. Biol. Chem. 255:5475-5480.

42. Milne, R. W., R. Theolis, Jr., R. B. Verdery, and Y. L. Marcel. 1983. Characterization of monoclonal antibodies against human low density lipoprotein. Arteriosclerosis. 3:23-30.

43. Tikkanen, M. J., T. G. Cole, and G. Schonfeld. 1983. Differential reactivity of human low density lipoproteins with monoclonal antibodies. J. Lipid Res. 24:1494-1499.

44. Tsao, B. P., L. K. Curtiss, and T. S. Edington. 1982. Immunochemical heterogeneity of human plasma apolipoprotein B. II. Expression of apolipoprotein B epitopes on native lipoproteins. J. Biol. Chem. 257:15222-15228.

45. Curtiss, L. K., and T. S. Edington. 1982. Immunochemical heterogeneity of human plasma apolipoprotein B. I. Apolipoprotein B binding of mouse hybridoma antibodies. J. Biol. Chem. 253:1521315221.

46. Mao, S. J. T., R. E. Kazmar, J. C. Silverfield, M. C. Alley, K. Kluge, and C. G. Fathman. 1982. Immunochemical properties of human low density lipoproteins as explored by monoclonal antibodies: binding characteristics distinct from those of conventional serum antibodies. Biochim. Biophys. Acta. 713:365-374.

47. Eisenberg, S. 1976. Metabolism of very low density lipoproteins. In Lipoprotein Metabolism. H. Greten, editor. Springer-Verlag New York Inc., New York. 32-43.

48. Howell, K. E., and G. E. Palade. 1982. Heterogeneity of lipoprotein particles in hepatic Golgi fractions. J. Cell Biol. 92:833845.

49. Gianturco, S. H., A. M. Gotto, Jr., J. B. Karlin, S. C. Prasad, and W. A. Bradley. 1983. Low density lipoprotein (LDL) receptor binding determinants switch from apolipoprotein (apo)E to apoB during conversion of hypertriglyceridemic very low density lipoprotein (HTG-VLDL) to LDL. Fed. Proc. 43:1820. (Abstr.)

50. Blum, C. B., L. Aron, and R. Sciacca. 1980. Radioimmunoassay studies of human apolipoprotein E. J. Clin. Invest. 66:1240-1250.

51. Cole, T. G., W. Patsch, I. Kuisk, B. Gonen, and G. Schonfeld. 1983. Increases in dietary cholesterol and fat raise levels of apoproteinE-containing lipoproteins in the plasma of man. J. Clin. Endocrinol. Metab. 56:1108-1115.

52. Gibson, J. C., A. Rubinstein, P. R. Bukberg, and W. V. Brown. 1983. Apolipoprotein E-enriched lipoprotein subclasses in normolipidemic subjects. J. Lipid Res. 24:886-898. 